NBER WORKING PAPER SERIES

\title{
MULTINATIONALS, TECHNOLOGY, AND THE INTRODUCTION OF VARIETIES OF GOODS
}

Irene Brambilla

Working Paper 12217

http://www.nber.org/papers/w12217

\section{NATIONAL BUREAU OF ECONOMIC RESEARCH \\ 1050 Massachusetts Avenue \\ Cambridge, MA 02138}

May 2006

I would like to thank J. Altonji, S. Berry, P. Goldberg, G. Grossman, J. Harrigan, R. Hellerstein, B. Honore, W. Keller, A. Pakes, R. Pande, G. Porto, E. Tamer, S. Yeaple, and seminar participants at Columbia, Industrial Development Conference, Federal Reserve Bank of New York, University of Pennsylvania, University of Texas at Austin, and Yale for helpful comments, and P. Keefer for access to the data.

(C) 2006 by Irene Brambilla. All rights reserved. Short sections of text, not to exceed two paragraphs, may be quoted without explicit permission provided that full credit, including (C notice, is given to the source. 
Multinationals, Technology, and the Introduction of Varieties of Goods

Irene Brambilla

NBER Working Paper No. 12217

May 2006, Revised August 2009

JEL No. F23,F12,F14

\begin{abstract}
$\underline{\text { ABSTRACT }}$
Multiproduct firms and product turnover are widespread phenomena. This paper develops a theoretical framework that links advantages in R\&D and variable costs with firm's ability to expand its portfolio of products. The framework is then applied to explain systematic differences in product introduction by affiliates of multinationals and firms that only operate domestically. Using firm-level data for the Chinese manufacturing sector during 1998\{2000, I compare the performance of foreign and domestic firms in terms of the new varieties that they introduce and I estimate the quantitative relevance of technological factors as a determinant.

I find that firms with more than 50 percent of foreign ownership introduce on average more than twice as many more new varieties of goods as private domestic firms. Advantages in productivity account for 32 to 62 percent of the difference in the number and sales of new varieties, while advantages in the cost of development account for 3 to 6 percent of these differences.
\end{abstract}

Irene Brambilla

Yale University

Department of Economics

37 Hilllhouse

P. O. Box 208264

New Haven, CT 06520-8264

and NBER

irene.brambilla@yale.edu 


\section{Introduction}

In a world with product differentiation and economies of scope, it is not surprising that most firms are multiproduct. Product turnover is also a widespread phenomenon, as firms tend to grow through their extensive margin in addition to their intensive margin. ${ }^{1}$ A firm's ability to expand through product diversification has consequences in terms of market share, growth and long-term survival, both domestically and in international markets.

At the heart of this issue is understanding what determines a firm's ability to develop new product varieties. The possibilities range from demand driven factors such as brand recognition, access to export markets, and ability to produce high-quality varieties, to cost-side explanations such as R\&D capability, variable productivity, and availability of distribution networks. This paper focuses on technology-based explanations. I develop a theoretical framework that links advantages in R\&D and variable costs with firm's ability to expand its portfolio of products.

The theoretical framework can be applied to explain systematic differences in product introduction by affiliates of multinationals and firms that only operate domestically. For multinational firms, because they can introduce the same variety in several markets, technological differences relevant to the issue of product introduction can arise from the possibility to diffuse fixed costs of R\&D across locations, and from learning by doing in production across affiliates. I document the advantage of multinationals in product introduction and estimate the quantitative relevance of technological factors using a dataset of Chinese manufacturing firms.

Horizontal multinationals have a cost advantage in the expansion of their product range because they can introduce the same products in several countries. When a domestic firm is looking to introduce a new variety, it is faced with the full cost of development. An affiliate of a multinational, on the other hand, can introduce a variety that the same corporate group is already producing elsewhere. In the extreme, a firm that is producing a good abroad can introduce that same good into the local market at zero marginal cost. In a less extreme case, local affiliates need to incur some development expenditures so as to adapt the good to the local market, advertise, and set up production. The initial cost of development, however, is diffused across countries and firms with production in several countries can more cheaply introduce a new variety than firms that only operate in one location. Learning by doing in production setup can also help reduce the local

\footnotetext{
${ }^{1}$ Bernard, Redding and Schott (2009), for example, document that multiproduct firms account for 91 percent of output in the U.S. manufacturing sector, and that one half of firms alter their product mix (defined at the relatively aggregate 5 digit level) every 5 years.
} 
costs. $^{2}$

Similar arguments apply to technology to introduce new products that is obtained from outside sources; for example, by purchasing a license. If a license is valid to produce in many countries, then the license cost faced by a local affiliate is only a fraction of the total cost. In the case that a license is needed for each affiliate, it can be expected that by acquiring licenses for several affiliates multinationals will have more bargaining power than local firms and will be able to obtain the licenses at better prices.

When making a decision to expand their product range firms consider variable profits in addition to the costs of development discussed above. Multinational firms tend to enjoy technological advantages in the variable cost side that will make introduction of new varieties more profitable and thus worth paying the cost of development. One source of such advantage is learning by doing across countries. When a firm is producing a variety worldwide the different affiliates may benefit from improvements in production processes and organization abroad, which reduce variable costs. Firms that operate abroad may also be more productive because of selection. Melitz (2003) and Helpman, Melitz and Yeaple (2004) describe how transport costs and fixed costs of entry to foreign markets can only be afforded by the most productive firms. Eaton and Kortum (2002) and Bernard, Eaton, Jensen, and Kortum (2003) develop Ricardian models where the most productive firms, net of transport costs, are the only suppliers in a given market.

I formalize these ideas in a static partial equilibrium model of horizontal differentiation and monopolistic competition à la Melitz (2003), with firms that can choose to produce more than one variety. Firms are heterogeneous in two dimensions: they face different fixed costs of development and production setup of each variety, and they bear different marginal costs of production. A firm finds that introducing a particular variety is profitable when the cost of development is lower than variable profits. This is more likely to happen when a firm faces lower average costs of development and of production. On average more efficient firms introduce a larger number of goods than their less advantaged counterparts. Domestic firms and affiliates of multinationals are different in the distribution of these costs, which leads them to make different decisions in terms of product introduction.

The model extends Melitz (2003) by allowing two dimensions of heterogeneity and multiple products. Having a second dimension of heterogeneity breaks the deterministic relation between

\footnotetext{
${ }^{2}$ A similar idea is explored in Criscuolo, Haskel and Slaughter (2005), where firms that export or invest abroad have access to a larger stock of knowledge through contact with clients and suppliers and between affiliates.
} 
firm size and productivity, thus generating realistic predictions in which firms that are equally productive need not make the same choices, and where firms that introduce a different number of varieties might be of the same size.

I apply the arguments described in the model to the study of the number of new varieties introduced by foreign and domestic manufacturing firms in China during the period 1998-2000. There are several reasons why China makes a good case study. The notion that multinational firms have a technical advantage due to repetition of production and introduction of varieties across countries is best suited to countries that are recipients of FDI and where domestic firms do not generally invest abroad, rather than to countries where headquarters are located. China has received a considerable amount of FDI in the last decade, accounting for about one third of FDI in all emerging markets and 60 percent of FDI in Asian emerging markets according to Prasad and Wei (2005). In 2003 China became the largest overall recipient of FDI in the world, a position that was previously occupied by the U.S. Additionally, a large fraction of FDI in China has taken place in the form of greenfield investment, as opposed to the acquisition of domestic plants by foreign firms. When a new production plant is set up from scratch there is more room for heterogeneity between foreign and domestic firms.

I find that firms with more than 50 percent of foreign ownership introduce on average more than twice as many new goods as private domestic firms. This advantage is enjoyed only by firms with foreign ownership that are indeed partially owned by a foreign firm, as opposed to firms that are merely owned by a foreign investor, indicating that it is the interaction among parents and affiliates what creates a production efficiency. Advantages in productivity account for 32 to 62 percent of the difference in the number and sales of new varieties; while advantages in the cost of development account for 3 to 6 percent of these differences.

The hypothesis of economies of scale and learning by doing enjoyed by multinational firms cannot be formally tested. The data, however, provide some support to the idea that technical advantages of foreign firms go beyond selection: average productivity is higher for foreign firms even after restricting the distribution of domestic firms to have the same truncation point as foreign firms. Economies of scale and learning by doing suggest that the advantage of multinationals in product introduction is self-perpetuating.

Firms that engage in international transactions have been found to outperform firms that only operate domestically in several dimensions. There is evidence that exporters are more 
productive, more capital and skill intensive, and pay higher wages than non-exporters (Clerides, Lach and Tybout, 1998, Bernard and Jensen, 1999, and 2004). Similarly, affiliates of multinational corporations have also been shown to outperform domestic firms in recipient countries in terms of wages (Feenstra and Hanson, 1997), while headquarters are thought to spend more in R\&D and to have better rates of innovation and patenting than firms that do not operate abroad (Caves, 1996, and Markusen, 2002, describe traditional stylized facts; Criscuolo, Haskel and Slaughter, 2005, provide more recent evidence on innovation by multinational and exporting firms). Firms that get involved in international commerce are also thought to enjoy higher growth rates. This paper contributes to this literature by adding evidence on a different outcome: product introduction.

The remaining of the paper is organized as follows: Section 2 presents the model; Section 3 discusses the data and compares the performance of foreign and domestic firms in terms of number and sales of new varieties; Section 4 explores the differences in productivity and development costs and their link to the expansion of the product portfolio; Section 5 concludes.

\section{A model of multiproduct firms}

Consumers are identical and their preferences are represented by a CES utility function over a continuum of differentiated goods in $\left[0, n^{*}\right]$. Let $q_{i}$ be the demanded quantity of variety $i$, and $\sigma>1$ the elasticity of substitution across the different varieties; the utility function is

$$
U=\left[\int_{0}^{n^{*}} q(i)^{\frac{\sigma-1}{\sigma}} d i\right]^{\frac{\sigma}{\sigma-1}}
$$

Given the exogenous income $y$ and prices $p_{i}$, the resulting demand function for each variety is

$$
q_{i}=p_{i}^{-\sigma} P^{\sigma-1} y
$$

where $P$ is the Dixit-Stiglitz price index defined by

$$
P=\left[\int_{0}^{n^{*}} p(i)^{1-\sigma} d i\right]^{\frac{1}{1-\sigma}}
$$

On the production side, there is a continuum of firms indexed by $j$ over the interval $[0, J]$. Each firm produces a measure $n(j)$ of differentiated varieties. The aggregate measure of different 
varieties $n^{*}$ satisfies

$$
n^{*}=\int_{0}^{J} n(j) d j
$$

Hereafter, I will refer to $J, n(j)$ and $n^{*}$ as the number of firms and varieties; it should be understood that each is a continuum.

The production technology is represented by a cost function for each variety $i$ produced by firm $j$ that takes the form

$$
C^{i j}\left(q_{i j}\right)=F_{i j}+c_{i j} q_{i j}
$$

$F_{i j}$ is the fixed cost of developing and setting up production of variety $i$ by firm $j$, while $c_{i j}$ is the marginal cost of production. ${ }^{3}$ For simplicity $F_{i j}$ includes both the cost of R\&D and the fixed cost of production. Note that the fixed and variable costs are not necessarily the same for different varieties produced by the same firm.

The decision of how many varieties to develop and produce involves two steps. First, firms need to gather information on the characteristics of potential varieties (i.e. the cost function in equation (5)). Firms cannot gather information on an infinite number of varieties since this activity involves time and effort. ${ }^{4}$ Learning the cost function of a number $N_{j}$ of potential varieties has a cost $\gamma\left(N_{j}\right)$, where $\gamma$ is a strictly increasing and convex function that satisfies $\gamma(0)=0$. For simplicity the cost of information $\gamma$ is the same for all firms. Once firms are aware of the costs of R\&D and production of a number $N_{j}$ of varieties they decide which of these varieties to introduce into the market. This decision is based on the profit opportunities that each variety presents.

The number of varieties introduced by each firm is assumed to be small enough relative to the total number of varieties in the market, so that the effect of one firm in the aggregate price index is negligible and the index is taken as given in the profit maximization problem. Strategic effects across varieties produced by the same firm are disregarded as well, for the same reason. Under this assumption firms act as monopolists over a residual demand with constant elasticity $\sigma$ for each of their varieties. ${ }^{5}$

\footnotetext{
${ }^{3}$ In Dixit and Stiglitz (1977) firms are homogeneous, while in Melitz (2003) firms differ in their variable costs. Hallak and Sividasan (2009) also look at two dimensions of heterogeneity.

${ }^{4}$ The idea that gathering information about varieties is costly is similar to the idea from the incomplete contract literature that including provisions for each contingency is not free. See Battigalli and Maggi (2002) for a model of endogeneity of the degree of completeness of a contract.

${ }^{5}$ Ottaviano and Thisse (1999), Baldwin and Ottaviano (2001), and Eckel and Neary (2008) model the behavior of multiproduct firms in an oligopolistic setting in which firms take cannibalization of own products into account when making a decision on the number of varieties. Arkolakis and Muendler (2007) study a setting of monopolistic competition. Nocke and Yeaple (2006) assume independent demands for different products produced by a same firm.
} 
The firms' decision-making process is described by the following sequence: (1) Firms decide whether to to enter the market or not. If they enter: (2) they gather information about potential varieties; (3) they decide which of these varieties to develop and introduce into the market; (4) they choose a price for each variety. There is a cost associated to each stage.

Firms are homogeneous before entry. To enter the market they need to pay a sunk fee $S$, which represents legal, organizational and basic setup costs. The sunk fee is independent of the number of varieties that each firm later chooses to produce and therefore creates economies of scope in the number of varieties.

Upon entry firms learn their firm type, that is, how efficient they are in $R \& D$ and production. The firm type is represented by a pair $\left(\bar{F}^{j}, \bar{c}^{j}\right)$, which are the expected fixed and variable costs of $\mathrm{R} \& \mathrm{D}$ and production in cost function (5). The pair is drawn from a distribution $G_{1}($.$) , common$ to all firms. The actual costs of $\mathrm{R} \& \mathrm{D}$ and production of each variety, $F_{i j}$ and $c_{i j}$, are stochastic functions of $\left(\bar{F}^{j}, \bar{c}^{j}\right)$.

Expected profits are decreasing in the number of firms in the market. Firms enter until ex-ante expected profits (before learning their firm type) are equal to the sunk fee, so that net expected profits are zero. This determines the equilibrium number of firms, $J$.

After entry and before engaging in the development of products, firms obtain information on the development and production costs of different varieties by taking draws of $\left(F_{i j}, c_{i j}\right)$ from distributions $G_{2}\left(F_{i j} \mid \bar{F}^{j}\right)$ and $G_{3}\left(c_{i j} \mid \bar{c}^{j}\right)$, where $\bar{F}^{j}$ and $\bar{c}^{j}$ are the mean of $F_{i j}$ and $c_{i j}$. The functions $G_{2}$ and $G_{3}$ are the same for all firms, however, the innovation and production efficiency parameters $\left(\bar{F}^{j}, \bar{c}^{j}\right)$ differ across firms and thus so does the distribution of $\left(F_{i j}, c_{i j}\right)$.

The activity of collecting information is costly and firms need to choose how many varieties to explore. Firms compute the expected profits of gathering information about $N_{j}$ varieties, which has an associated cost of $\gamma\left(N_{j}\right)$, and choose this number optimally depending on their efficiency parameters. More efficient firms are more likely to find that introducing a particular variety is profitable and thereby have incentives to gather information on a larger number of varieties than less efficient firms. A firm may choose to explore zero varieties, which is equivalent to exiting the market immediately after entry.

Once firms have the information on the cost of innovation and production cost of $N_{j}$ varieties, all uncertainty is resolved. Firms then decide which of the potential varieties to introduce into the market based on the fixed and variable costs learnt in the previous stage and represented by the cost 
function (5). Given the assumptions on market structure and production technology, firms make a separate decision about each variety that depends solely on whether variable profits from sales net of fixed innovation and production costs are larger than zero. The total number of varieties introduced by firm $j$ is given by $n_{j}$. After the firms have decided which varieties to introduce they make price decisions subject to the residual demand faced for each variety.

The firm decision process is solved backwards. In the last stage, taking the varieties that are introduced as given, firms choose the prices that maximize variable profits given by $\left(p_{i j}-c_{i j}\right) q\left(p_{i j}\right)$. Under the CES utility assumption prices are determined by a constant mark-up over the production cost that depends on the elasticity of substitution, $p_{i j}=\frac{\sigma}{\sigma-1} c_{i j}$. Indirect profits are

$$
\pi_{i j}=k c_{i j}{ }^{1-\sigma} P^{\sigma-1} y-F_{i j}
$$

with $k=\frac{(\sigma-1)^{\sigma-1}}{\sigma^{\sigma}}$.

Firms decide which varieties to introduce based on their information on $c_{i j}$ and $F_{i j}$ and the profit maximizing prices. A variety is introduced if $\pi_{i j} \geq 0$; with $n_{j}$ denoting the number of varieties for which $\pi_{i j} \geq 0$.

Next, firms decide how many varieties to investigate based on the information that they have on their firm type, $\left(\bar{F}^{j}, \bar{c}^{j}\right)$, and prior to the realizations of $\left(F_{i j}, c_{i j}\right)$. With the information on firm type they compute the probability of introducing a variety, $\operatorname{Pr}\left(\pi_{i j} \geq 0 \mid \bar{F}^{j}, \bar{c}^{j}\right)$, and the expected profit of a successful variety, $E\left[\pi_{i j} \mid \pi_{i j} \geq 0 ; \bar{F}^{j}, \bar{c}^{j}\right]$. Note that the probability of successfully introducing a variety and the expected profit from each successful variety are identical across varieties for a same firm and do not depend on $N_{j}$. Firms maximize total expected profits net of the cost of information $\gamma($.$) ,$

$$
\max _{N_{j}} \operatorname{Pr}\left(\pi_{i j} \geq 0 \mid \bar{F}^{j}, \bar{c}^{j}\right) E\left[\pi_{i j} \mid \pi_{i j} \geq 0 ; \bar{F}^{j}, \bar{c}^{j}\right] N_{j}-\gamma\left(N_{j}\right)
$$

Finally, when firms are deciding whether to enter the market or not, they compute the ex-ante expected profits prior to learning their firm type. Mathematically this means integrating the maximized objective function (7) over the distribution of firm types $G_{1}$. Firms enter until ex-ante expected profits are equal to the entry fee $S .{ }^{6}$

Under these assumptions all firms are homogeneous prior to entry. Let us now introduce

\footnotetext{
${ }^{6}$ The condition is

$\int_{\bar{F}^{j}, \bar{c}^{j}}\left[\max _{N_{j}} \operatorname{Pr}\left(\pi_{i j} \geq 0 \mid \bar{F}^{j}, \bar{c}^{j}\right) E\left[\pi_{i j} \mid \pi_{i j} \geq 0 ; \bar{F}^{j}, \bar{c}^{j}\right] N_{j}-\gamma\left(N_{j}\right)\right] d G_{1}\left(\bar{F}^{j}, \bar{c}^{j}\right)=S$
} 
foreign and domestic firms and let them differ systematically. Foreign affiliates are part of larger corporations which are researching, developing and producing goods elsewhere. Some of the affiliates produce the same goods as the parents (or affiliates located elsewhere) and benefit from the corporation's experience in the production of the good, both in terms of R\&D (it is not necessary to develop a good from scratch if it is being produced elsewhere) and in terms of variable productivity (foreign firm have organizational advantages, for example).

The differences between foreign and domestic firms can be expressed as differences in the function $G_{1}$. Efficiency of foreign firms is ruled by a cumulative distribution function $G_{1}^{F}($.$) , while$ efficiency of domestic firms depends on $G_{1}^{D}($.$) . G_{1}^{D}($.$) first order stochastically dominates G_{1}^{F}($. in both arguments, which implies that foreign firms are on average more efficient in $R \& D$ and in production. Foreign firms face a higher entry fee than domestic firms, represented by $S^{F}$ and $S^{D}$, respectively. ${ }^{7}$ Both types of firms face ex-ante zero profits in equilibrium.

It is important to notice that the distribution $G_{1}^{F}($.$) refers to efficiency of foreign firms in the$ host country. Efficiency in the host country reflects both innate (exogenous) efficiency of the firm, which we can think of as efficiency in the country of origin, and endogenous gains in efficiency via international learning by doing and diffusion of fixed costs.

The variable of interest is the expected number of products introduced by firms and how it relates to technology and firm's origin. Results can be summarized in the following predictions.

Proposition 1: The number of products introduced by firm $j, n_{j}$, is approximated by a Poisson distribution with parameter $E\left(n_{j} \mid \bar{F}^{j}, \bar{c}^{j}\right)=\operatorname{Pr}\left(\pi_{i j} \geq 0 \mid \bar{F}^{j}, \bar{c}^{j}\right) N_{j}\left(\bar{F}^{j}, \bar{c}^{j}\right)$.

Proof: Firm $i$ takes $N_{j}$ independent draws of $\left(F_{i j}, c_{i j}\right)$ and, for each of these draws, it evaluates whether profits are greater than zero. Each of these profit evaluations is an independent Bernoulli trial with the same probability of success $\operatorname{Pr}\left(\pi_{i j} \geq 0 \mid\right.$.). Thus, the number of successes follows a Binomial distribution, that is, $\operatorname{Pr}\left(n_{j}=n \mid \bar{F}^{j}, \bar{c}^{j}\right)=\frac{N_{j}(.)}{n !\left(N_{j}(.)-n\right) !} \operatorname{Pr}\left(\pi_{i j} \geq 0 \mid .\right)^{n} \operatorname{Pr}\left(\pi_{i j}<0 \mid .\right)^{N_{j}(.)-n}$. Applying the limiting properties of the Binomial distribution, as the number of trials becomes large and the probability of success becomes small, the distribution of the number of products is approximated by a Poisson. ${ }^{8}$

\footnotetext{
${ }^{7}$ Several authors argue that set up costs are higher for firms entering a foreign market (either via exports or FDI) due to differences in consumers' preferences, language, regulations, etc. For the FDI case, see Helpman, Melitz and Yeaple (2004).

${ }^{8} \lim _{N_{j} \rightarrow \infty, \operatorname{Pr}\left(\pi_{i j} \geq 0 \mid .\right) \rightarrow 0} \operatorname{Pr}\left(n_{j}=n \mid().\right)=\frac{\left(\operatorname{Pr}\left(\pi_{i j} \geq 0 \mid .\right) N_{j}(.)\right)^{n} \exp \left(-\operatorname{Pr}\left(\pi_{i j} \geq 0 \mid .\right) N_{j}(.)\right)}{n !}$. The notion of $N_{j}$ becoming large and $\pi_{i j}>0$ becoming small is consistent with a setting in which variations of similar products (such as quality upgrades or changes in colors, format or packaging) are viewed as different varieties.
} 
Proposition 2: The expected number of products introduced by firm $j, E\left(n_{j} \mid \bar{F}^{j}, \bar{c}^{j}\right)$, is decreasing in the cost parameters $\bar{F}^{j}$ and $\bar{c}^{j}$.

Proof: The expected number of products can be written as $E\left(n_{j} \mid.\right)=\operatorname{Pr}\left(\pi_{i j} \geq 0 \mid.\right) N_{j}($.$) .$ I show that $\operatorname{Pr}\left(\pi_{i j} \geq 0 \mid \bar{F}^{j}, \bar{c}^{j}\right)$ and $N_{j}\left(\bar{F}^{j}, \bar{c}^{j}\right)$ are decreasing in $\bar{F}^{j}$. First, substituting the cdfs of $F_{i j}$ and $c_{i j}\left(G_{2}\right.$ and $\left.G_{3}\right)$ and the definition of profits, we can write the probability of success as $\operatorname{Pr}\left(\pi_{i j} \geq 0 \mid \bar{F}^{j}, \bar{c}^{j}\right)=\int_{c_{i j}} G_{2}\left(k c_{i j}^{1-\sigma} P^{\sigma-1} \mid \bar{F}^{j}\right) d G_{3}\left(c_{i j} \mid \bar{c}^{j}\right)$. This term is decreasing in $\bar{F}^{j}$ since $G_{2}\left(. \mid \bar{F}^{j}\right)$ is decreasing in $\bar{F}^{j}$ by assumption. Second, based on equation $(7), N_{j}=$

$\operatorname{argmax}_{(N)}\left[\int_{c_{i j}} \int_{F_{i j}}\left(k c_{i j}^{1-\sigma} P^{\sigma-1} y-F_{i j}\right) d G_{2}\left(F_{i j} \mid \bar{F}^{j}\right) d G_{3}\left(c_{i j} \mid \bar{c}^{j}\right)\right] N-\gamma(N)$. The integral term is decreasing in $\bar{F}^{j}$ by the assumptions on $G_{2}$. Given that the function $\gamma$ is increasing and convex, $N_{j}$ is decreasing in $\bar{F}^{j}$. The proof for $\bar{c}^{j}$ is analogous and both proofs are generalizable to discrete variables.

Intuitively, relatively more efficient firms - in product development or in production - find on average that profits from a particular variety are higher than for less efficient firms. As a result both the probability of introducing a given variety and the number of varieties for which they gather information, $N_{j}$, are larger.

Proposition 3: Foreign firms introduce on average more products than domestic firms. $E\left(n_{j}\right)^{F} \geq E\left(n_{j}\right)^{D}$.

Proof: From Proposition 2 and since $G_{1}^{D}\left(\bar{F}^{j}, \bar{c}^{j}\right)$ stochastically dominates $G_{1}^{F}\left(\bar{F}^{j}, \bar{c}^{j}\right)$, we have that $\int_{\left(\bar{F}^{j}, \bar{c}^{j}\right)} E\left(n_{j} \mid \bar{F}^{j}, \bar{c}^{j}\right) d G_{1}^{F}\left(\bar{F}^{j}, \bar{c}^{j}\right) \geq \int_{\left(\bar{F}^{j}, \bar{c}^{j}\right)} E\left(n_{j} \mid \bar{F}^{j}, \bar{c}^{j}\right) d G_{1}^{D}\left(\bar{F}^{j}, \bar{c}^{j}\right)$. Then, $E\left(n_{j}\right)^{F} \geq E\left(n_{j}\right)^{D}$.

Foreign firms are on average more efficient in $\mathrm{R} \& \mathrm{D}$ and production and, thus, the expected number of products is higher. The effect of higher entry fees for foreign firms goes in the same direction.

\section{Comparing foreign and domestic firms}

In the next two sections I study the introduction of new varieties of goods by firms in the Chinese manufacturing sector and assess the roles played by advantages in productivity and R\&D costs, as described in the model.

The analysis is organized as follows. This section documents the advantage of foreign firms in the introduction of new varieties. After describing the data and detailing the empirical strategy, I present results from firm-level regressions of number of varieties on firm ownership. In Section 4 I 
look at technology-based differences across foreign and domestic firms, namely variable productivity (defined as value added per worker) and cost of $\mathrm{R} \& \mathrm{D}$. The empirical analysis concludes by studying how much of the advantage of foreign firms in introduction of new varieties is explained by these technological differences.

\subsection{Data}

I use firm-level data from the World Bank's 2001 Investment Climate Survey. This survey was run in collaboration with the Chinese National Bureau of Statistics and is part of a World Bank's larger project aimed to studying the business environment at the firm-level in Africa, Latin America, and South and East Asia. A total of 1,500 firms were interviewed in 2001 in five Chinese cities - Beijing, Tianjin, Shanghai, Guangzhou and Chengdu - by members of the Enterprise Survey Organization of the Chinese National Bureau of Statistics. The surveyed unit is the main production facility of a firm. The data include accounting information on sales, inputs, labor, stock of capital, investment and several other expenditures; and broader information such as ownership structure, characteristics of the labor force, relations with competitors, clients and suppliers, innovation, and market environment and investment climate.

One thousand of these firms correspond to 27 different 3-digit and 4-digit level industries in the Manufacturing sector, while the other 500 correspond to Services. The 27 industries were selected non-randomly with the purpose of focusing on the main sectors in China and on those with high growth and innovation rates. They can be categorized into 5 big groups: Apparel and Leather Goods, Household Appliances, Vehicles and Vehicle Parts, Electronic Equipment, and Electronic Components. ${ }^{9}$ Approximately two hundred firms were surveyed in each of these groups. Within these groups firms were chosen randomly and their composition is therefore representative of the population.

The data span the period 1998-2000, however, firms were interviewed only once, in 2001. As a result some questions are answered annually; while other answers involve information for the entire 3-year period. The accounting information on sales and input usage is annual. For these particular entries the data are equivalent to a 3-year panel with no entry and exit of firms. The questions on introduction of new varieties of goods are answered for the entire 3-year period. There

\footnotetext{
${ }^{9}$ There are 4 industries within the group "Apparel and Leather Goods;" 4 industries within "Household Appliances;" 11 industries within "Vehicles and Vehicle Parts;" 3 industries within "Electronic Equipment;" and 5 industries within "Electronic Components."
} 
is information on how many new varieties firms have introduced from the beginning of 1998 to the end of 2000, but not on how many per year.

A new variety does not necessarily constitute a new production line, or an innovation from the point of view of consumers. To be classified as "new" a variety needs to be different from all other varieties produced by the same firm, regardless of whether there is already a similar product in the Chinese market. A new variety includes true innovations, a new production line for a given firm, a horizontal increase in the product range, or an improvement in quality. The number of new varieties captures the extent to which a firm expands by increasing and replacing the range of products that they offer. From the point of view of the survey the definition of what constitutes a new variety is to some extent subjective to the firm. ${ }^{10}$

Table 1 provides descriptive statistics. After discarding plants that were established after 1998 and some outliers for which the reported number of new varieties is more than one hundred, ${ }^{11}$ the sample includes 878 manufacturing firms - 605 domestic firms and 273 foreign firms. Within domestic firms 47 percent are privately owned, 29 percent are state-owned, and 23 percent are cooperatives or collectively owned by workers. I define a firm as foreign when foreign participation in its capital is at least 10 percent. Of the 273 firms with some degree of foreign ownership, 72 percent are majority-owned foreign firms (16 percent are fully-owned foreign and 56 percent have foreign participation between 50 and 99 percent) while the remaining 28 percent have less than 50 percent of foreign ownership.

Columns 2 to 4 display the median number of workers in 1998, the average value added per worker in 1998, and the average number of new varieties introduced during the period 1998-2000, each by ownership type. The overall median number of workers is 274 . There are substantial differences across ownership types. State-owned firms are the largest (in terms of workers) and cooperatives, private domestic and fully-owned foreign firms are the smallest. The performance of foreign firms in terms of output per worker is better than the performance of domestic firms. Within foreign firms, those with more than 50 percent of foreign ownership outperform firms with less than 50 percent of foreign ownership; while within domestic firms, private ones do better than state-owned firms and cooperatives. Firms introduce on average 3.5 new varieties of goods;

\footnotetext{
${ }^{10}$ Given the subjectivity involved, different firms possibly follow different criteria. As long as the definitions of new varieties are uncorrelated to the ownership structure of the firms, the differences in criteria do not introduce a bias in the estimation.

${ }^{11}$ Discarded observations include both foreign and domestic firms and do not follow a particular pattern. More than 97 percent of firms report introducing less than 20 new goods, and only 10 firms report introducing more than a hundred new goods. I do not include the latter to avoid these outliers driving results.
} 
foreign firms are above this average (3.8 new varieties for firms with less than 50 percent of foreign ownership and 5.7 and 4.5 new varieties for firms with 50 percent or more of foreign ownership); while domestic firms are below this average (private firms introduce 2.9 new varieties on average, state-owned firms introduce 3.4 varieties and cooperatives 1.8 varieties).

\subsection{Varieties introduced by foreign and domestic firms}

\section{Empirical Strategy}

Following the model in section 2, I assume that the number of new varieties introduced by firm $j, n_{j}$, follows a Poisson distribution with parameter $\lambda_{j} \cdot{ }^{12}$ Under this assumption, the conditional probability that firm $j$ introduces $n_{j}$ new varieties is $P\left(n_{j} \mid \lambda_{j}\right)=\frac{\lambda_{j}^{n_{j}} e^{-\lambda_{j}}}{n_{j} !}$. Both the mean and the variance of the number of new varieties is given by $\lambda_{j}$. The parameter $\lambda_{j}$ is specific to each firm and it is a deterministic function of the ownership structure of the firm and the observable firm characteristics $x_{j}$. I adopt the log-linear specification ${ }^{13}$

$$
\lambda_{j}=\exp \left(x_{j}^{\prime} \beta_{0}+\beta_{1} F O R_{1 j}+\beta_{2} F O R_{2 j}+\beta_{3} N O N P R I V_{j}\right)
$$

The main variables of interest are the foreign ownership variables $F O R_{1}$ and $F O R_{2}$. These are indicator variables for firms with some degree of foreign ownership; firms with less than 50 percent of foreign participation in capital are included in $F O R_{1}$ (hereafter, minority-owned foreign firms), while $F O R_{2}$ comprises firms with foreign capital ranging from 50 to 100 percent (majority-owned foreign firms). ${ }^{14}$ The coefficients on these variables indicate the advantage of foreign firms over domestic firms in the introduction of new varieties. The variable NONPRIV is equal to one for non-private domestic firms, that is, state-owned enterprises and collectively-owned firms. Private domestic firms are the excluded category.

The exogeneity of the ownership type deserves some discussion as self-selection based on

\footnotetext{
${ }^{12}$ Different forms of the Poisson distribution are usually adopted when the dependent variable is a non-negative integer. In the innovation literature several authors model the number of patent applications as a Poisson process: Hausman, Hall and Griliches (1984) and Crepon and Duguet (1997) study the effect of expenditure on R\&D on patents; Blundell, Griffith and Van Reenen (1995) investigate the relation between patents and market power and stock of knowledge. Cameron and Trivedi (1998) describe general estimation issues.

${ }^{13}$ The log-linear specification is convenient because it guarantees that the expected number of new varieties is non-negative.

${ }^{14}$ Firms with exactly $50 \%$ of foreign capital are included in the majority group $F O R_{2}$. Regression results are not substantially different when the groups are defined taking 40 percent or 60 percent as cutoffs. I have also experimented with a continuous variable indicating the degree of foreign participation in a firm's capital obtaining a positive and significant coefficient (not shown). The dummy specification is preferred given that the relation appears to be non-linear.
} 
unobserved characteristics could be an issue. Foreign firms might choose to locate in cities or industries which provide a more favorable environment for product introduction, either because of better upholding of property rights, for example, or because of the innate characteristics of the product or industry-specific regulations. One can also think of scenarios in which ownership type is self-selected based on characteristics of the firms. For example, foreign firms may choose to buy out the Chinese firms that have more potential for good performance. Alternatively, the opposite might occur, domestic firms that are not performing well might seek foreign partners to improve business, or they might go bankrupt and get bought-out by a foreign firm; whereas domestic firms with well established networks and credit lines may not find it necessary to seek foreign associates.

Much of the foreign investment in China has been greenfield FDI, where foreign firms build their own plants. This greatly reduces the potential for self-selection problems that arise because of firm-level unobserved heterogeneity. Nonetheless, I address the potential self-selection issue by controlling and using proxies for unobserved characteristics that explain the ownership type and that could be also correlated with the number of varieties. To control for location and industry choices, I add city and industry effects to the regression. Throughout the paper, industry effects are defined at the highest level of disaggregation allowed by the data, that is, 27 industries at the 3 and 4 digit level. At the firm level, I add firm size, market power and age as controls. Back to the previous examples, foreign firms may associate with domestic firms based on their (partially unobserved) potential for performance. At the same time, this potential for performance (good or bad) is correlated with observed measures of performance, namely size and market power. More generally, the assumption is that unobserved characteristics that influence ownership decisions also influence firm size and market power. By adding these variables to the regression, my objective is to control for unobserved characteristics. Age is an observed measure of potential performance and it can affect both ownership decisions and introduction of new varieties.

I use the log number of workers as a measure of firm size. Since firms that introduce more varieties need to hire more workers, I use workers in 1998, the first year of data, to minimize reverse causality issues. Notice that the reason to include number of workers in the regression is not to identify the coefficient on number workers per se, but to use the number of workers as a scale variable that controls for unobserved firm characteristics. From this point of view, it is neither necessary nor desirable to instrument the number of workers. It is important to keep in mind, though, that the coefficient on number of workers has a reduced form interpretation with no 
predictive value for exogenous changes in this variable.

As firms with more market power have more incentives to invest in $R \& D$ and to introduce more goods, it is important to control for this variable. I use self-reported market share as a proxy. This gives rise to two issues. Firstly, firms that develop newer varieties gain a larger fraction of the market from its rivals, which introduces a simultaneity problem. Most importantly, because I use market share that is self-reported by firms in the survey, the measure is affected by the subjective perception of each firm, mainly the perception of what their relevant market is, thus leading to bias due to measurement error. I address these problems by instrumenting market power. The instruments I use are defined at the province-industry level: the net tax rate for private domestic firms, the median number of days it takes to obtain a telephone connection, the average number of legal disputes that firms have with clients and suppliers, and the average number of days of power outages. $^{15}$

Because the main regression is of Poisson type, the standard linear instrumental variable methods do not apply. Instead, I use a two-step control function approach as in Blundell and Powell (2003 and 2004). In the first step I run an OLS regression of market share on a fourth order polynomial of the instruments plus the other explanatory variables in regression (8) and compute the residuals. ${ }^{16}$ In the second step I estimate the Poisson regression including the residuals from the first step as a regressor. These residuals control for the endogeneity of the market share. Standard errors need to be corrected to account for the first stage, which I do by running a bootstrap with 500 replications.

Regarding age, there are several reasons why new firms might behave differently from established firms. One reason is uncertainty about their own ability, as in Jovanovic (1982), where firms get signals about their unobserved "firm type." This would lead them to proceed with caution and introduce fewer products at the beginning. On the other hand, newer firms might need to introduce

\footnotetext{
${ }^{15}$ The net tax rate is from the Provincial Statistical Yearbooks and corresponds to 1996. This variable is constructed comparing average profits of private domestic firms before and after taxes, and it comprises not only taxes that apply uniformly, but also fiscal incentives that may be granted, by province, to specific industries. The last three variables are reported by firms in the survey and aggregated by city and industry. Working at the firm level could have two problems. One problem is bias due to subjectivity about the business environment. A different problem is that some of these variables may not satisfy the exclusion restriction, while this issue is mitigated when aggregating the data at the city-industry level.

${ }^{16}$ The identifying assumptions of the first stage regression is not simply that the market share is correlated with the instruments and that the instruments are uncorrelated with the error term - as would be the case in the instrumental variables case- but rather that the first step regression function correctly specifies the econometric model that determines the market share. In addition, the error term in the first step regression is assumed to be uncorrelated to the error term in the second step regression. For this reason, a flexible functional form, such as a polynomial, is preferred to a linear specification of the first stage. More general non-parametric methods can also be used.
} 
varieties at a higher rate than established firms until they have reached a portfolio of products of optimal size, or to quickly establish a brand name. At the same time, age can be correlated with selection of ownership type. Under different scenarios, foreign firms might be more interested in associating with (or buying out) long-established firms, in order to get access to their networks or to minimize uncertainty, or with younger firms, assuming it is easier to have an influence on their management and production methods. In any of these scenarios, controlling for age becomes important. The regression also includes two dummy variables for firms that started operations in 1997 and in 1998, so as to allow for the possibility of a non-linear correlation with age for the case of very new firms.

Results

The first column of Table 2 displays the results of the Poisson regression (8) of the number of new varieties on firm ownership, including market power as a control. Because the regression function is not linear the interpretation of the coefficients is not straightforward. To provide a more intuitive interpretation of the results the table shows the coefficients and the incidence ratios $\exp \left(\beta_{k} \Delta x_{k}\right)$, which indicate the expected proportional change in the number of varieties. ${ }^{17}$ Results show that, other things equal, firms with more than 50 percent of foreign participation introduce 2.46 times as many new varieties as private domestic firms. Firms with foreign capital between 10 and 50 percent, on the other hand, actually introduce less varieties than private domestic firms, although the difference is not statistically significant. Non-private firms introduce 73 percent of the number of varieties introduced by private domestic firms.

Columns 2 and 3 report results from the two-stage Poisson regression, where market power is instrumented following a control function approach. ${ }^{18}$ Column 3 adds firm size as an additional control for unobserved heterogeneity. Results are in line with the previous specification, indicating that majority-owned foreign firm introduce more than twice as many new goods as domestic firms. The coefficient on column 3, when size is added as a control, are smaller than in the previous two columns (0.8 versus 0.90 and 0.86 ). This confirms the idea that, when unobserved heterogeneity is not accounted for, there is a positive self-selection effect that leads to overestimation of the coefficients. The coefficient on log age also drops in column 3 relative to columns 1 and 2, from positive to statistically not significant. This result is consistent with the idea that both firm size

\footnotetext{
${ }^{17}$ For continuous regressors the incidence ratio is computed for a 10 percent change.

${ }^{18}$ Results from the first stage regression are discussed in the Appendix.
} 
and age are correlated with unobserved firm characteristics, such as potential for future good performance.

For the sake of comparison, in column 4, size, as well as market power, is instrumented. In this case, the coefficient of log workers does have a causal interpretation. ${ }^{19}$ The coefficient on majority-owned foreign firms slightly goes down when size is instrumented, but it is still of large magnitude and significant, implying that even after controlling for size, foreign firms introduce about twice as many new products as domestic firms. Notice that this result implies that the relation between firm size and product introduction is not one-to-one and is inconsistent with a theoretical setting in which firms differ in only one dimension, for example in variable costs.

As a test of sensitivity to the functional form specification, column 5 displays the results of a linear IV regression, where market share is instrumented. ${ }^{20}$ The expectation is in this case a linear function of the regressors and the coefficients can be interpreted directly: majority-owned foreign firms introduce on average 3.7 more new varieties than private domestic firms. To compare these numbers with the Poisson results it is necessary to compute the difference in the expected number of new varieties between majority-owned foreign firms and private domestic firms in the Poisson specification. ${ }^{21}$ This difference is 2.9 for the two-stage Poisson specification of column 3 .

\section{Ownership Types}

The firm survey includes information on whether the foreign owners are foreign firms or foreign investors. The distinction between firms and investors is relevant in this case. The hypothesis is not that foreign capital per se makes a difference in terms of introducing more varieties, but that a firm's experience abroad, both in research and development and in production, is what provides an advantage. From this point of view, only firms operating in China that are owned by foreign firms, and not simply foreign investors, should have an advantage.

This hypothesis is explored in the last two columns of Table 2. In Column 6, majority-owned foreign firms are split into those that are a joint venture of a foreign and a domestic firm and those

\footnotetext{
${ }^{19}$ Care must be taken in interpreting this regression as, once workers are instrumented, part of the unobserved heterogeneity becomes unaccounted for. Given that the coefficient on the majority-owned dummy goes down from column 1 to column 3, as controls for unobserved heterogeneity are added, one can interpret the coefficient on column 4 as an upper bound for the coefficient on foreign firms once size is controlled for.

${ }^{20}$ As additional tests, I have also run regressions for a Poisson-Gamma mixture (Negative Binomial) and a Zero-Inflated Poisson specification. There are no substantial differences in the results.

${ }^{21}$ The Poisson incidence ratios provide a percentage increment in the number of goods; while the linear coefficients represent absolute differences in the number of goods. Evaluated at the mean, the difference in expected values is given by $\exp \left(\bar{x}^{\prime} \beta_{0}+\beta_{2}\right)-\exp \left(\bar{x}^{\prime} \beta_{0}\right)$.
} 
who are partially owned by a foreign investor without production activities elsewhere. The evidence supports that it is foreign production activities which provide an advantage, not simply foreign ownership. Firms operating in China that are partially owned by foreign enterprises introduce as many as 3.2 times more new varieties than private domestic firms. Firms operating in China that are partially owned by foreign investors do not have an advantage when compared with private domestic firms; as a matter of fact, these firms actually do worse than domestic firms. Column 7 considers fully-owned foreign firms separately. There are few fully-owned foreign firms in the survey and the confidence intervals are too large to make inferences. The point estimates suggest that the advantage of fully-owned foreign firms (multinationals) is even higher than the advantages of majority-owned foreign firms.

\section{Technology determinants}

The model in Section 2 describes two dimensions of firm-level heterogeneity that explain why firms choose to introduce a different number of varieties: efficiency in production and efficiency in research and development. In this section I investigate whether there exist systematic differences in these two dimensions of heterogeneity between domestic and foreign firms and assess the impact that both dimensions have on the number of varieties introduced by a firm. I decompose the total difference in the number of varieties introduced by domestic and foreign firms into the fractions explained by differences in productive efficiency and efficiency in $R \& D$. We expect foreign firms to be more efficient in production due to learning from their experience in other countries, and to have lower costs of $R \& D$ in China because part of this cost has been incurred to introduce the same new varieties in other markets.

To measure efficiency in production I compute measures of variable productivity. I define variable productivity as value added per worker, and, alternatively, as total factor productivity estimated by the method developed by Olley and Pakes (1996). I approximate efficiency in development with expenditure in R\&D and purchases of technology from outside sources per new variety. ${ }^{22}$ For foreign firms I consider expenditure by Chinese affiliates only, as the intention is to

\footnotetext{
${ }^{22}$ These measures are an approximation to variable and fixed costs that originate from accounting information. As such, they are subject to misrepresentation by the firms. One important case would be transfer pricing, whereby, given the usually favorable tax rates in China, foreign firms would tend to report higher sales in China and higher costs of R\&D abroad. This would lead to overestimation of their efficiency (in China) both in variable productivity and lower costs of development. Other measurement issues could appear due to differences in the quality of products, which is not accounted for in the data. Additionally, the number of workers (used to construct variable productivity)
} 
capture the cost of introducing new varieties in China, not worldwide. I also compare the preferred ways of getting access to new varieties across firms.

\subsection{Are foreign firms more productive?}

Figure 1 shows the empirical density functions of the logarithm of labor productivity for private domestic firms and majority-owned foreign firms (50 percent to 100 percent) for 12 of the 27 industries included in the survey (the selected industries are those with the largest number of observations). Labor productivity is defined as value added per worker in 1998, the first year of data. The graphs provide a first visual inspection of the distribution of productive efficiency of foreign and domestic firms. The first two graphs correspond to Apparel and Leather Products. There is no evidence that foreign firms have a productivity advantage in these industries. In all remaining sectors the density of labor productivity for majority-owned foreign firms lies to the right of the density of private domestic firms, which implies that foreign firms are on average more productive.

As a more formal test for evidence of the existence of productivity advantages in foreign firms, I regress labor productivity on ownership structure and firm characteristics. The regression function takes the following form,

$$
\log P R O D_{j}=x_{j}^{\prime} \delta_{0}+\delta_{1} F O R_{j}^{1}+\delta_{2} F O R_{j}^{2}+\delta_{3} N O N P R I V_{j}+\mu_{j}
$$

The ownership structure dummies are the same as in the Poisson regression: FOR $R^{1}$ and $F O R^{2}$ are dummies for minority and majority-owned foreign firms, and NONPRIV indicates that the firm is domestic and state or collectively owned. Other control variables are the book value of the stock of capital, age, and industry and city effects. Since ownership variables are time invariant during the sample there is no advantage from incorporating different time periods and the regression reduces to a cross-section of firms.

Results are displayed in Table 3. Majority-owned foreign firms are on average 36 percent more productive than private domestic firms (column 1); minority-owned foreign firms do not have a productive advantage; while state and collectively-owned firms are 60 percent less efficient than private firms. Column 2 splits majority-owned foreign firms into those owned by a firm that

could also include workers affected to R\&D. As a robustness check, I have also worked with production workers only and results are unchanged (these results are not shown for the sake of space). 
operates abroad and those owned by a foreign investor. It is confirmed that only those firms that are partially owned by a firm operating abroad have an efficiency advantage, instead of all firms with foreign ownership. Column 3 separates majority-owned foreign firms into four categories: subsidiaries of multinationals, firms fully owned by foreign investors, firms partially owned by a firm operating abroad, and firms partially owned by foreign investors. Production advantages are found for subsidiaries of multinationals and firms partially owned by a firm operating abroad. The productive advantages with respect to private domestic firms are 119 percent and 75 percent. This last finding supports the hypothesis of improved technical efficiency through interactions of parents and affiliates: firms owned by multinationals and firms operating abroad can take advantage of the experience that they have developed in other countries, while firms owned by investors cannot. Results are qualitatively similar when variable productivity is defined as total factor productivity (TFP), estimated from a Cobb-Douglas production function with the investment-proxy method developed by Olley and Pakes (1996) (columns 4 to 6). ${ }^{23}$

\section{Productivity and Selection}

Possible selection of foreign firms into most productive industries and cities is controlled for with industry and city effects. There is still a potential selection effect if firms of different origin face systematic differences in the costs of entry, as in Melitz (2003) and Helpman, Melitz and Yeaple (2004). ${ }^{24}$ Only firms with variable profits above the fixed cost of entry will be able to enter and stay in the market. If the fixed cost of entry is higher for foreign firms than for domestic firms, the required profit level is also higher for foreign firms. If differences in variable profits depend solely on differences in productivity, the entry condition can be written as a cutoff level for productivity, with the cutoff productivity being higher for foreign firms. In this situation the truncated observed productivity levels are on average higher for foreign firms even in the case that the distributions of productivities are the same for both types of firms (conditional on the costs of R\&D).

I address this question by estimating truncations in the distribution of productivity for majority-owned foreign firms. Consider the distribution of productivity levels in one sector, and assume there is a cutoff, so that the productivity levels of observed firms are all above the cutoff

\footnotetext{
${ }^{23} \mathrm{TFP}$ is computed as the residual of a regression of log value added on log capital, log labor, and city and industry effects. Regressions are run at the level of industry groups, thus, I estimate 5 different production functions for the 5 industry groups in the survey (Apparel and Leather Goods, Electronic Equipment, Electronic Components, Household Appliances, and Vehicles and Vehicle Parts).

${ }^{24}$ Even another selection problem arises in the case of mergers and acquisitions, since foreign firms may be inclined to choose the most productive domestic firms.
} 
(firms below the cutoff exit and are not captured in the data). Asymptotically the lowest realized value of productivity converges to the cutoff. Following this argument I estimate the cutoffs for majority-owned foreign firms in each sector by choosing the firm with the lowest measured productivity. ${ }^{25}$

In Table 3, columns 7 to 9, I reestimate the regressions of productivity on ownership excluding private domestic firms with productivity below the cutoffs for majority-owned foreign firms in each sector. In this case majority-owned foreign firms are 28 percent more productive than their private domestic counterparts. This difference increases to 76 and 110 percent when we consider firms owned by a foreign firm and subsidiaries of multinationals.

Note that this is not a test for the existence of cutoffs in productivity levels, or a test that allows us to draw conclusions about the shape of the full distribution of productivity. The regression is a robustness check: majority-owned foreign firms are substantially more productive than domestic firms, even when the less productive domestic firms are not included in the comparison. This indicates that the distributions are indeed different according to origin of the firm. Consider two scenarios: one in which the productivity distributions are identical between foreign and domestic firms; and one in which the productivity distribution of foreign firms first-order stochastically dominates de distribution of domestic firms. The results of the test are interpreted as being consistent with the second scenario and not consistent with the first one. ${ }^{26}$

The idea that the productivity distribution of foreign firms dominates the distribution of domestic firms is not implausible given the results in columns 7-9 and most of the graphs in Figure (1). To collect additional evidence, I run quantile regressions at the top of the productivity distribution. Positive coefficients in the quantile regressions support the notion that the productivity distributions do not cross. ${ }^{27}$ Table 3 displays the results from quantile regressions approximating the 75 th percentile in columns 10 to 12 . The point estimates provide evidence that the efficiency advantage of foreign firms is higher at the top of the distribution (i.e. the coefficients of the quantile regressions are larger than the baseline regression), except for subsidiaries of multinationals, where the opposite result holds. However, the confidence intervals of the estimates are fairly large, and the difference between estimates across regressions is not statistically significant.

\footnotetext{
${ }^{25}$ Formally, the cutoff in sector $k$ for majority-owned foreign firms is defined by $\min _{j}\left\{P R O D_{j} \mid j\right.$ is a majority-owned foreign firm in industry $\left.h\right\}$.

${ }^{26}$ Strictly speaking, the test cannot distinguish between scenarios in which the productivity cumulative density functions of foreign and domestic firms cross each other.

${ }^{27}$ Notice that, though necessary, this is not a sufficient condition for first order stochastic dominance of the sample without selection.
} 
Results are very similar when the 90th percentile is estimated (not shown).

\subsection{Is the cost of development lower for foreign firms?}

To address the question of whether foreign firms have a cost advantage in the introduction of new goods, I look at the expenditure on R\&D plus expenditure on purchases of technology from outside sources over the period 1998-2000 per dollar sold of new varieties that the firm successfully introduced in China. This is a proxy for the average fixed cost of introducing new goods. For foreign multinationals I consider expenditure on R\&D by the Chinese affiliates only, as the purpose of this section is to document differences in efficiency in R\&D in China, not worldwide. This reflects the notion that multinational firms can be more efficient in China, relatively to domestic firms, because they can diffuse fixed costs of R\&D across international markets. ${ }^{28}$

Table 4 shows the results of a regression of this proxy for development costs on ownership structure categories (defined as in the previous sections). The regressions include only firms that introduce a strictly positive number of new varieties, as the development cost is not available for firms that do not introduce new varieties. Since the choice of number of varieties is not modeled in this section, results need to be interpreted as a correlation.

Controlling for self-reported market share, logarithm of age, dummies for firms that started operating in 1997 and 1998, and industry and city effects, majority-owned foreign firms enjoy a 59 percent development cost advantage compared to private domestic firms (column 1). When instrumenting market share, the advantage for majority-owned foreign firms is 54 percent (column 3). Columns 2 and 4 split foreign firms into those owned by foreign companies and by foreign investors. As expected, it is firms owned by foreign companies that are more efficient. However, the difference in $R \& D$ efficiency between the two types of foreign firms is not nearly as striking as the difference in efficiency in production. Possibly this is because the proxy for development costs includes purchases of licenses and presumably foreign investors could have advantages in getting access to license sources compared to Chinese domestic firms.

As additional evidence on lower fixed cost of development I look at the mode in which firms introduce new products: whether they have transferred at least one new variety from a company in the same corporate group, whether they have purchased at least one license for a new product

\footnotetext{
${ }^{28}$ To the extent that multinational firms could incur in R\&D expenditures abroad for China-specific varieties, estimations of the relative efficiency of multinational and domestic firms using this proxy for average fixed costs are an upper bound.
} 
from a foreign source, and whether they have developed at least one new variety in-house (for multinational firms, this means in the affiliates located in China). The mode of introduction of new varieties is not related to differences in variable productivity but rather it reflects the lowest cost of development. A propensity of foreign firms to transfer technology from abroad is an indication of scale economies in development.

I run three different probit regressions among firms that did introduce a positive number of new varieties with the three modes of introduction as the dependent variable (the three modes are not mutually exclusive since firms can follow different strategies for different varieties). The explanatory variables are ownership structure, captured by the same categories defined before (majority-owned foreign, minority-owned foreign, private domestic, non-private), the logarithm of the number of workers, the logarithm of age, dummy variables for firms that started production in 1997 and 1998, and industry and city fixed-effects. Results are displayed in Table 5 and can be interpreted straightforwardly: majority-owned foreign firms are 20 percent more likely to transfer new products from a firm in a the same corporate group than private domestic firms are, they are 31 percent more likely to purchase at least one foreign license, and they are 23 percent less likely to develop products in-house. All results are statistically significant. The difference in the probability of occurrence of any of these three events is not significant for minority-owned foreign firms and state and collectively-owned firms (the baseline category is private domestic firms). These findings support the idea that foreign firms can take advantage of the development costs that have been already incurred abroad by the same firm and that they do not need to develop new products in the Chinese affiliate as much as domestic Chinese firms do.

\subsection{How much does each factor explain?}

The previous findings support the idea that foreign firms have a cost advantage over domestic firms, both in terms of variable costs and in the fixed cost of incorporation of new varieties. In this section I estimate the extent to which these differences affect the ability of firms to introduce new varieties of goods.

I reestimate the regressions that explain the number of new varieties including efficiency in production and in development as explanatory variables. Only firms that introduce a positive number of new varieties are included in the regressions and thus the distribution of the dependent variable needs to be adjusted to account for the truncation. This means estimating a Poisson 
regression conditional on the number of varieties being strictly positive.

Results are reported in Table 6 (Panel A). The specifications of the first two columns match columns 1 and 3 of Table 2, that is, a Poisson regression without instruments and without controlling for size, and a Poisson regression where market power is instrumented and log workers is included as a control. Both efficiency variables are significant and have the expected signs: firms introduce more varieties the higher the variable productivity and the lower the fixed costs of development. Ownership types do not have explanatory power once efficiency has been accounted for, which suggests that the advantage of foreign firms in the introduction of new varieties is largely explained by technological advantages. Similar results are obtained, though most coefficients are not statistically significant, when majority-owned foreign firms are split into those owned by a firm and those owned by an investor.

The case of firms owned by foreign investors is very interesting. Unlike almost all coefficients on dummy variables denoting ownership type, the absolute values of the coefficients on foreign investors dummies remain substantially high after controlling for technological factors. This speaks of differences that are not related to technology. ${ }^{29}$ One possible explanation could be agency issues arising from the type of partnership. Foreign shareholders need to rely on local technology since they are not a firm with production experience abroad. Local technology is provided by a local partner, who receives at most 49 percent of the surplus. Under these conditions, the local partner might choose to withhold its innovation-related knowledge and introduce fewer varieties although they are not less efficient than purely domestic firms.

The role of efficiency in explaining the difference in performance between foreign and domestic firms is further explored in Panel B of Table 6 by performing a decomposition. Here I compute the predicted average number of new varieties for two different groups: majority-owned foreign firms and private domestic firms in columns 1 and 2, and majority-owned joint ventures and private domestic firms in columns 3 and 4 . I calculate what percentage of the difference in the two predicted index functions is accounted for by the productivity and cost factors. Let PROD and COST denote labor productivity and cost of development, and let $F$ and $D$ index majority-owned foreign and

\footnotetext{
${ }^{29}$ These results are consistent with Tables 2,3 and 4 , which show that foreign firms owned by investors are at a disadvantage with respect to private domestic firms in the introduction of new varieties (Table 2), but not when it comes to technology (Tables 3 and 4).
} 
private domestic firms. The percentage contribution of labor productivity is given by

$$
\frac{\widehat{\beta}_{P R O D}\left(\overline{P R O D}_{F}-\overline{P R O D}_{D}\right)}{\left(\bar{x}_{F}-\bar{x}_{D}\right)^{\prime} \widehat{\beta}_{0}+\widehat{\beta}_{P R O D}\left(\overline{P R O D}_{F}-\overline{P R O D}_{D}\right)+\widehat{\beta}_{C O S T}\left(\overline{C O S T}_{F}-\overline{C O S T}_{D}\right)},
$$

where $\widehat{\beta}$ are the coefficients from Panel A and $\overline{P R O D}, \overline{C O S T}$, and $\bar{x}$ are the means of labor productivity, development cost, and the control variables for the two groups of firms (majority-owned foreign and private domestic). The definition of the contribution of COST is analogous.

Panel B of Table 6 shows the decomposition. Differences in labor productivity between foreign and domestic firms explain between 32 and 62 percent of the predicted advantage of foreign firms in the introduction of new varieties. Differences in the cost of R\&D and purchases of new technology explain around 3 to 6 percent of this advantage. Together the two technology factors explain from 39 to 65 percent. Industry and geographic location also play an important role in explaining differences in introduction of new varieties across foreign and domestic firms, ranging from 11 to 45 percent in the different specifications. Factors that have not been included in the analysis, such as differences in domestic demand, exporting behavior, distribution networks and relations with retailers, are grouped within the "unexplained" category and account for 5 percent to 50 percent of the difference. It is interesting to notice that the unexplained factors are much less relevant in the specifications where log workers are included as a control and instruments are used for market power. $^{30}$ Size and market power do not play a big role in explaining the difference; while initial year of operations appears to have a negative influence. ${ }^{31}$

\section{Conclusion}

This paper describes the role of firm technological heterogeneity in expansion strategies through increases and renovations of the product portfolio of multinational and domestic firms. While the role of firm heterogeneity has been largely studied in the context of trade and FDI; the contribution of this paper is twofold. First, it studies heterogeneity as a determinant of the introduction of several

\footnotetext{
${ }^{30}$ This finding gives further support to the use of size as a control for unobserved heterogeneity. The low explanatory power of unexplained factors also suggests that domestic firms might have an advantage over foreign firms in these dimensions, which would also explain why, despite being at a disadvantage from the point of view of technology, domestic firms can achieve the same size as foreign firms.

${ }^{31}$ Negative contributions indicate that the variable explains a relative disadvantage of foreign firms.
} 
varieties of goods. Second, it focuses on differences in the cost of development and productive efficiency that, for foreign firms, arise from diffusion of fixed costs and learning by doing across international affiliates. From the point of view of trade theory, the paper extends the model in Melitz (2003) to a setting with two dimensions of firm heterogeneity and more than one product.

The data for the Chinese manufacturing sector support the hypotheses that multinational firms have technical advantages and that these play an important role in the introduction of varieties. Foreign affiliates with more than 50 percent of foreign capital do indeed expand their product portfolio more than twice as much as domestic firms. This result does not hold for foreign firms which are owned by foreign investors, indicating that the fact that the same firm has production facilities elsewhere matters.

Differences in labor productivity and the cost of development are significant across foreign and domestic firms, with the former being more efficient in both dimensions. The advantages in variable productivity seem to be caused by differences in productivity distributions and not solely by selection.

Overall, heterogeneity in technology explains between 39 and 65 percent of the advantage in product expansion by foreign firms (differences in labor productivity account from 32 to 62 percent, and differences in cost of development between 3 and 6 percent). Industry and geographic location also play an important role in explaining this difference, ranging from 11 to 45 percent.

\section{Appendix}

Results from a linear version of the first-stage regression of market shares and log workers on the instruments are displayed in Table A1. Column 1 shows that the average number of days to setup a telephone connection is a good instrument to explain market power, while column 2 shows that three of the four instruments are highly correlated with number of workers. In the Poisson regressions of Table 2, I use a polynomial so that the functional form is more flexible, which is desirable from a point of view of specification (see footnote 16). The polynomial includes second order terms in the first three instruments (tax rate, days to setup a phone, and legal disputes) and fourth order terms in power outages and log age. 


\section{References}

Arkolakis, C. and M. Muendler (2007): "The Extensive Margin of Exporting Goods: A Firm-level Analysis," mimeo.

Baldwin, R. and G. Ottaviano (2001): "Multiproduct Multinationals and Reciprocal Dumping," Journal of International Economics, Vol. 54, 429-448.

Battigalli, P. and G. Maggi (2002): "Rigidity, Discretion, and the Costs of Writing Contracts," The American Economic Review, Vol. 92, No. 4, 798-817.

Bernard, A. and B. Jensen (1999): "Exceptional Exporter Performance: Cause, Effect, or Both?," Journal of International Economics, Vol. 47, 1-25.

Bernard, A. and B. Jensen (2004): "Exporting and Productivity in the USA," Oxford Review of Economic Policy, Vol. 20, No. 3, Autumn, 343-357.

Bernard, A., J. Eaton, B. Jensen, and S. Kortum (2003): "Plants and Productivity in International Trade," American Economic Review, Vol. 93, No. 4, September, 1268-1290.

Bernard, A., S. Redding and P. Schott (2009): "Multi-Product Firms and Product Switching," forthcoming American Economic Review.

Blundell, R., R. Griffith and J. Van Reenen (1995): "Dynamic Count Data Models of Technological Innovation," Economic Journal, Vol. 105, No. 429, March, 333-344.

Blundell, R. and J. Powell (2003): "Endogeneity in Nonparametric and Semiparametric Regression Models," Advances in Economics and Econometrics: Theory and Applications, ed. by M. Dewatripont, L. P. Hansen and S. Turnovsky, Vol. 2, Econometric Society Monograph \#36, Cambridge University Press, Cambridge.

Blundell, R. and J. Powell (2004): "Endogeneity in Semiparametric Binary Response Models," Review of Economic Studies, Vol. 71, No. 3, 655-679.

Cameron, A.C. and P. Trivedi (1998): Regression Analysis of Count Data, Cambridge University Press, Cambridge.

Caves, R. (1996): Multinational Enterprise and Economic Analysis. Cambridge University Press, London.

Clerides, S., S. Lach and J. Tybout (1998): "Is Learning by Exporting Important? Micro-Dynamic Evidence from Colombia, Mexico, and Morocco," The Quarterly Journal of Economics, Vol. 113, No. 3, August, 903-947.

Crepon, B. and E. Duguet (1997): "Research and Development, Competition and Innovation. Pseudo-Maximum Likelihood and Simulated Maximum Likelihood Methods Applied to Count Data Models with Heterogeneity," Journal of Econometrics, Vol. 79, 355-378.

Criscuolo, C., J. E. Haskel and M. J. Slaughter (2005): "Global Engagement and the Innovation Activities of Firms," NBER Working Paper Working Paper No. 11479, July.

Dixit, A. and J. Stiglitz (1977): "Monopolistic Competition and Optimum Product Diversity," The American Economic Review, Vol. 67, No. 3, June, 297-308. 
Eaton, J. and S. Kortum (2002): "Technology, Geography, and Trade," Econometrica, Vol. 70, No. $5,1741-1779$.

Eckel, C. and P. Neary (2008): "Multi-Product Firms and Flexible Manufacturing in the Global Economy," University College Dublin, Department of Economics.

Feenstra, R. and G. Hanson (1997): "Foreign Direct Investment and Relative Wages: Evidence from Mexico's Maquiladoras," Journal of International Economics, Vol. 42, 371-394.

Hallak, J. C., and J. Sivadasan (2009): "Firm's Exporting Behavior Under Quality Requirements," NBER Working Paper No. 14928

Hausman, J., B. Hall, and Z. Griliches (1984): "Econometric Models for Count Data with an Application to the Patents-R\&D relationship," Econometrica, Vol. 52, No. 4, July, 909-938.

Helpman, E., M. Melitz and S. Yeaple (2004): "Export versus FDI with Heterogeneous Firms," The American Economic Review, Vol. 94, No. 1, March, 300-316.

Jovanovic, B. (1982): Selection and the Evolution of Industry, Econometrica, Vol. 50, No. 3, May, 649-670

Melitz, M. (2003): "The Impact of Trade on Intra-Industry Reallocations and Aggregate Industry Productivity," Econometrica, Vol. 71, No. 6, Nov., 1695-1725.

Nocke, V. and S. Yeaple (2006): "Globalization and Endogenous Firm Scope," NBER Working Paper No. 12322.

Olley, G.S. and A. Pakes (1996): "The Dynamics of Productivity in the Telecommunications Equipment Industry," Econometrica, Vol. 64, No. 6, Nov., 1263-1297.

Ottaviano, G. and J-F. Thiesse (1999): "Monopolistic Competition, Multiproduct Firms, and Optimal Product Diversity," CEPR Discussion Paper No. 2151.

Prasad, E. and S-J. Wei (2005): "Chinas Approach to Capital Inflows: Patterns and Possible Explanations," in S. Edwards ed., International Capital Flows, University of Chicago Press 
Figure 1: Distribution of Labor Productivity
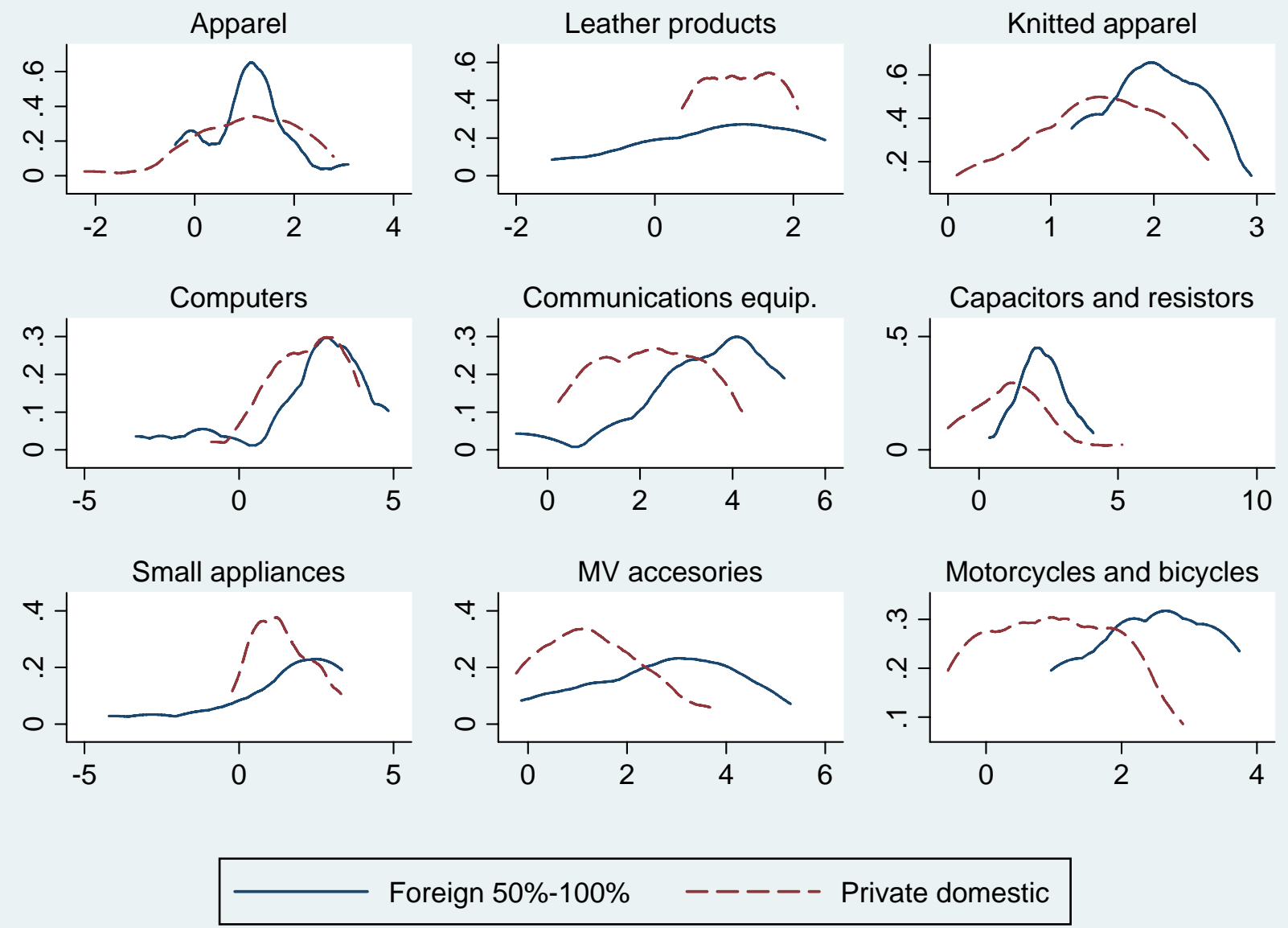

Density functions of labor productivity in 1998 for majority-owned foreign firms and private domestic firms. Labor productivity is computed as value added per worker. 
Table 1: Summary Statistics

\begin{tabular}{lcccc}
\hline Type of firm & $\begin{array}{c}\text { Number of } \\
\text { firms } \\
(1)\end{array}$ & $\begin{array}{c}\text { Median number } \\
\text { of workers } \\
(2)\end{array}$ & $\begin{array}{c}\text { Average value added } \\
\text { per worker }\end{array}$ & $\begin{array}{c}\text { Average number } \\
\text { of new products }\end{array}$ \\
\hline Private domestic & 287 & 180 & $(3)$ & $(4)$ \\
State-owned & 176 & 637 & 8.1 & 2.9 \\
Cooperative & 142 & 138 & 3.1 & 3.4 \\
Foreign 10\%-50\% & 76 & 210 & 3.6 & 1.8 \\
Foreign 50\%-99\% & 153 & 312 & 10.8 & 3.8 \\
Foreign 100\% & 44 & 161 & 19.2 & 4.7 \\
Total & 878 & 274 & 17.1 & 3.5 \\
\hline
\end{tabular}

Source: own calculations based on The World Bank 2001 Chinese Investment Climate Survey. 
Table 2: New Varieties and Foreign Ownership

\begin{tabular}{|c|c|c|c|c|c|c|c|}
\hline & (1) & $(2)$ & $(3)$ & $(4)$ & $(5)$ & $(6)$ & $(7)$ \\
\hline Majority (50-100\%) & $0.90^{* * *}$ & $0.86^{* * *}$ & $0.8^{* *}$ & $0.76^{* *}$ & $3.67^{* *}$ & - & - \\
\hline Incidence ratio & $\begin{array}{c}2.46 \\
(0.31)\end{array}$ & $\begin{array}{l}2.35 \\
(0.31)\end{array}$ & $\begin{array}{c}2.23 \\
(0.32)\end{array}$ & $\begin{array}{c}2.11 \\
(0.39)\end{array}$ & (1.69) & & \\
\hline $\begin{array}{l}\text { Majority }(50-100 \%) \times \mathrm{JV} \\
\quad \text { Incidence ratio }\end{array}$ & - & - & - & - & - & $\begin{array}{c}1.17^{* * *} \\
3.21 \\
(0.35)\end{array}$ & $\begin{array}{c}1.1^{* * *} \\
3.00 \\
(0.36)\end{array}$ \\
\hline $\begin{array}{l}\text { Majority }(50-100 \%) \times \mathrm{INV} \\
\quad \text { Incidence ratio }\end{array}$ & - & - & - & - & - & $\begin{array}{c}-1.36^{* * *} \\
0.26 \\
(0.45)\end{array}$ & $\begin{array}{c}-1.22^{* *} \\
0.30 \\
(0.52)\end{array}$ \\
\hline $\begin{array}{l}\text { Fully }(100 \%) \times \mathrm{SUB} \\
\quad \text { Incidence ratio }\end{array}$ & - & - & - & - & - & - & $\begin{array}{c}1.54^{*} \\
4.68 \\
(0.86)\end{array}$ \\
\hline $\begin{array}{l}\text { Fully }(100 \%) \times \mathrm{INV} \\
\text { Incidence ratio }\end{array}$ & - & - & - & - & - & - & $\begin{array}{c}-1.67 \\
0.19 \\
(2.75)\end{array}$ \\
\hline Minority (10-49\%) & -0.22 & -0.36 & -0.37 & -0.42 & -0.88 & -0.41 & -0.41 \\
\hline Incidence ratio & $\begin{array}{c}0.81 \\
(0.28)\end{array}$ & $\begin{array}{c}0.70 \\
(0.32)\end{array}$ & $\begin{array}{c}0.69 \\
(0.32)\end{array}$ & $\begin{array}{c}0.66 \\
(0.35)\end{array}$ & $(1.14)$ & $\begin{array}{c}0.66 \\
(0.31)\end{array}$ & $\begin{array}{c}0.66 \\
(0.32)\end{array}$ \\
\hline $\begin{array}{l}\text { Non-private } \\
\text { Incidence ratio }\end{array}$ & $\begin{array}{c}-0.33 \\
0.72 \\
(0.24)\end{array}$ & $\begin{array}{c}-0.43^{* *} \\
0.65 \\
(0.22)\end{array}$ & $\begin{array}{c}-0.35 \\
0.71 \\
(0.23)\end{array}$ & $\begin{array}{c}-0.30 \\
0.74 \\
(0.30)\end{array}$ & -0.97 & $\begin{array}{l}-0.38^{*} \\
(0.22)\end{array}$ & $\begin{array}{l}-0.38^{*} \\
(0.22)\end{array}$ \\
\hline $\begin{array}{l}\text { Log Workers } \\
\quad \text { Incidence ratio }\end{array}$ & - & - & $\begin{array}{c}0.2^{* * *} \\
1.22 \\
(0.07)\end{array}$ & $\begin{array}{c}0.33 \\
1.40 \\
(0.42)\end{array}$ & $0.70^{* *}$ & $0.23^{* * *}$ & $\begin{array}{c}0.24^{* * *} \\
(0.08)\end{array}$ \\
\hline Market Share & $\begin{array}{l}0.01^{* *} \\
(0.00)\end{array}$ & $\begin{array}{l}-0.01 \\
(0.03)\end{array}$ & $\begin{array}{l}-0.01 \\
(0.03)\end{array}$ & $\begin{array}{l}-0.02 \\
(0.03)\end{array}$ & $\begin{array}{l}-0.01 \\
(0.12)\end{array}$ & $\begin{array}{l}-0.02 \\
(0.03)\end{array}$ & $\begin{array}{l}-0.02 \\
(0.03)\end{array}$ \\
\hline Log Age & $\begin{array}{l}0.36^{* *} \\
(0.16)\end{array}$ & $\begin{array}{c}0.38^{* * *} \\
(0.15)\end{array}$ & $\begin{array}{c}0.22 \\
(0.15)\end{array}$ & $\begin{array}{c}0.09 \\
(0.43)\end{array}$ & $\begin{array}{c}0.82 \\
(0.65)\end{array}$ & $\begin{array}{l}0.27^{*} \\
(0.15)\end{array}$ & $\begin{array}{l}0.26^{*} \\
(0.15)\end{array}$ \\
\hline Setup 1998 & $\begin{array}{c}0.53 \\
(0.52)\end{array}$ & $\begin{array}{c}0.48 \\
(0.54)\end{array}$ & $\begin{array}{c}0.66 \\
(0.58)\end{array}$ & $\begin{array}{c}0.64 \\
(0.58)\end{array}$ & $\begin{array}{c}3.16 \\
(2.94)\end{array}$ & $\begin{array}{c}0.75 \\
(0.55)\end{array}$ & $\begin{array}{c}0.76 \\
(0.54)\end{array}$ \\
\hline Setup 1997 & $\begin{array}{c}0.49 \\
(0.37)\end{array}$ & $\begin{array}{c}0.26 \\
(0.36)\end{array}$ & $\begin{array}{c}0.12 \\
(0.35)\end{array}$ & $\begin{array}{c}0.09 \\
(0.44)\end{array}$ & $\begin{array}{c}0.59 \\
(1.34)\end{array}$ & $\begin{array}{c}0.19 \\
(0.37)\end{array}$ & $\begin{array}{c}0.20 \\
(0.36)\end{array}$ \\
\hline $\begin{array}{l}\text { Observations } \\
\text { R-squared }\end{array}$ & 685 & 680 & 661 & 661 & $\begin{array}{l}661 \\
0.08\end{array}$ & 653 & 653 \\
\hline
\end{tabular}

Dependent variable: Number of new varieties of goods introduced by the firm from 1998 to 2000. Column 1: Poisson; Columns 2, 3, 6, 7: IV Poisson where market share is instrumented; Column 4: IV Poisson where market share and log workers are instrumented; Column 5: 2SLS where market share is instrumented. Domestic private firms are the baseline category. Majority and Minority: indicator variables for foreign firms, according to the participation of foreign ownership in capital. Majority JV: foreign joint venture; Majority INV: foreign firms owned by investors; Fully SUB: subsidiary of a foreign multinational; FULLY INV: fully-owned foreign firm, owned by an investor. Non-private: domestic firms owned by the State or by a cooperative. Setup 1998 and Setup 1997: indicator variables for plants that started operating in those years. Regressions include city and industry effects. Robust standard errors in parenthesis (bootstrapped in the case of IV Poisson); SE computed for coefficients, not incidence rations; ${ }^{*}$ significant at $10 \%$; $* *$ significant at $5 \%$; $* * *$ significant at $1 \%$. 
Table 3: Efficiency in Production

\begin{tabular}{|c|c|c|c|c|c|c|}
\hline \multirow[b]{2}{*}{ Panel A } & \multicolumn{3}{|c|}{ Log VA per worker } & \multicolumn{3}{|c|}{ TFP (Olley \& Pakes) } \\
\hline & (1) & $(2)$ & $(3)$ & (4) & $(5)$ & (6) \\
\hline Majority (50-100\%) & $\begin{array}{c}0.36^{* * *} \\
(0.14)\end{array}$ & - & - & $\begin{array}{c}0.18^{* *} \\
(0.09)\end{array}$ & - & - \\
\hline Majority $(50-100 \%) \times \mathrm{JV}$ & - & $\begin{array}{c}0.82^{* * *} \\
(0.14)\end{array}$ & $\begin{array}{c}0.75^{* * *} \\
(0.15)\end{array}$ & - & $\begin{array}{c}0.37^{* * *} \\
(0.09)\end{array}$ & $\begin{array}{c}0.34^{* * *} \\
(0.09)\end{array}$ \\
\hline Majority $(50-100 \%) \times$ INV & - & $\begin{array}{l}-0.23 \\
(0.24)\end{array}$ & $\begin{array}{l}-0.07 \\
(0.21)\end{array}$ & - & $\begin{array}{l}-0.1 \\
(0.15)\end{array}$ & $\begin{array}{l}0.08 \\
(0.18)\end{array}$ \\
\hline Fully $(100 \%) \times$ SUB & - & - & $\begin{array}{c}1.19^{* * *} \\
(0.24)\end{array}$ & - & - & $\begin{array}{c}0.56^{* * *} \\
(0.18)\end{array}$ \\
\hline Fully $(100 \%) \times$ INV & - & - & $\begin{array}{l}-0.53 \\
(0.51)\end{array}$ & - & - & $\begin{array}{l}-0.45^{*} \\
(0.24)\end{array}$ \\
\hline Minority (10-49\%) & $\begin{array}{c}0.22 \\
(0.16)\end{array}$ & $\begin{array}{c}0.24 \\
(0.16)\end{array}$ & $\begin{array}{c}0.23 \\
(0.16)\end{array}$ & $\begin{array}{l}-0.16 \\
(0.10)\end{array}$ & $\begin{array}{l}-0.15 \\
(0.10)\end{array}$ & $\begin{array}{l}-0.15 \\
(0.10)\end{array}$ \\
\hline Non-private & $\begin{array}{c}-0.60^{* * *} \\
(0.13)\end{array}$ & $\begin{array}{c}-0.60^{* * *} \\
(0.13)\end{array}$ & $\begin{array}{c}-0.60^{* * *} \\
(0.13)\end{array}$ & $\begin{array}{c}-0.35^{* * *} \\
(0.08)\end{array}$ & $\begin{array}{c}-0.35^{* * *} \\
(0.08)\end{array}$ & $\begin{array}{c}-0.35^{* * *} \\
(0.08)\end{array}$ \\
\hline $\begin{array}{l}\text { Observations } \\
\text { R-squared }\end{array}$ & $\begin{array}{l}796 \\
0.3\end{array}$ & $\begin{array}{c}783 \\
0.33\end{array}$ & $\begin{array}{l}783 \\
0.34\end{array}$ & $\begin{array}{c}823 \\
0.552\end{array}$ & $\begin{array}{c}810 \\
0.562\end{array}$ & $\begin{array}{c}810 \\
0.565\end{array}$ \\
\hline Panel B & Firn & $\begin{array}{l}\text { is above c } \\
(8)\end{array}$ & off & $\begin{array}{l}\text { Quanti } \\
\text { (10) }\end{array}$ & $\begin{array}{l}\text { Regressi } \\
\text { (11) }\end{array}$ & $\begin{array}{r}\mathrm{n}(\mathrm{p} 75) \\
(12)\end{array}$ \\
\hline Majority (50-100\%) & $\begin{array}{c}0.28^{* *} \\
(0.13)\end{array}$ & - & - & $\begin{array}{c}0.51^{* * *} \\
(0.19)\end{array}$ & - & - \\
\hline Majority $(50-100 \%) \times \mathrm{JV}$ & - & $\begin{array}{c}0.76^{* * *} \\
(0.14)\end{array}$ & $\begin{array}{c}0.69 * * * \\
(0.15)\end{array}$ & - & $\begin{array}{c}0.79 * * * \\
(0.20)\end{array}$ & $\begin{array}{c}0.80^{* * *} \\
(0.21)\end{array}$ \\
\hline Majority $(50-100 \%) \times \mathrm{INV}$ & - & $\begin{array}{l}-0.31 \\
(0.23)\end{array}$ & $\begin{array}{l}-0.15 \\
(0.21)\end{array}$ & - & $\begin{array}{l}-0.14 \\
(0.24)\end{array}$ & $\begin{array}{l}-0.12 \\
(0.29)\end{array}$ \\
\hline Fully $(100 \%) \times J V$ & - & - & $\begin{array}{c}1.10^{* * *} \\
(0.24)\end{array}$ & - & - & $\begin{array}{l}0.91^{* *} \\
(0.39)\end{array}$ \\
\hline Fully $(100 \%) \times \operatorname{INV}$ & - & - & $\begin{array}{l}-0.62 \\
(0.51)\end{array}$ & - & - & $\begin{array}{l}-0.26 \\
(0.37)\end{array}$ \\
\hline Minority (10-49\%) & $\begin{array}{c}0.15 \\
(0.15)\end{array}$ & $\begin{array}{c}0.17 \\
(0.15)\end{array}$ & $\begin{array}{c}0.17 \\
(0.15)\end{array}$ & $\begin{array}{c}0.31 \\
(0.24)\end{array}$ & $\begin{array}{c}0.27 \\
(0.21)\end{array}$ & $\begin{array}{l}0.29 \\
(0.21)\end{array}$ \\
\hline Non-private & $\begin{array}{c}-0.64^{* * *} \\
(0.12)\end{array}$ & $\begin{array}{c}-0.64^{* * *} \\
(0.12)\end{array}$ & $\begin{array}{c}-0.65^{* * *} \\
(0.12)\end{array}$ & $\begin{array}{l}-0.35^{*} \\
(0.19)\end{array}$ & $\begin{array}{c}-0.37^{* *} \\
(0.16)\end{array}$ & $\begin{array}{c}-0.36^{* *} \\
(0.16)\end{array}$ \\
\hline $\begin{array}{l}\text { Observations } \\
\text { R-squared }\end{array}$ & $\begin{array}{l}789 \\
0.3\end{array}$ & $\begin{array}{c}776 \\
0.339\end{array}$ & $\begin{array}{c}776 \\
0.342\end{array}$ & 796 & 783 & 783 \\
\hline
\end{tabular}

Dependent variable: 1-3,7-12 Log value added per worker in 1998; 4-6 Average log TFP. Columns 7-9 exclude private domestic firms with productivity below minimum for foreign firms. Domestic private firms are the baseline category. Majority $\times(\mathrm{JV}$ or INV) includes firms of up to $100 \%$ of foreign ownership in columns 2, 5, 8 and 11 , and up to $99 \%$ of foreign ownership in columns 3,6,9 and 12. Other controls: log capital, log age, city and industry effects. Robust standard errors in parenthesis; * significant at $10 \% ; * *$ significant at $5 \%$; ** significant at $1 \%$. 
Table 4: Expenditure in New Varieties

\begin{tabular}{lcccc}
\hline & OLS & OLS & IV & IV \\
& $(1)$ & $(2)$ & $(3)$ & $(4)$ \\
\cline { 2 - 5 } Majority (50-100\%) & $-0.59^{* *}$ & - & $-0.54^{*}$ & - \\
Majority $(50-100 \%) \times \mathrm{JV}$ & $(0.30)$ & & $(0.30)$ & \\
& - & $-0.68^{* *}$ & - & $-0.66^{* *}$ \\
Majority (50-100\%)×INV & - & $(0.30)$ & & $(0.31)$ \\
& & -0.43 & - & -0.35 \\
Minority (10-49\%) & $-0.71^{*}$ & $-0.73^{*}$ & -0.64 & $-0.69^{*}$ \\
& $(0.39)$ & $(0.38)$ & $(0.40)$ & $(0.39)$ \\
Non-private & 0.28 & 0.28 & 0.35 & 0.32 \\
& $(0.29)$ & $(0.30)$ & $(0.32)$ & $(0.31)$ \\
Log Age & $-0.34^{*}$ & $-0.39^{* *}$ & $-0.35^{*}$ & $-0.40^{* *}$ \\
& $(0.17)$ & $(0.17)$ & $(0.18)$ & $(0.18)$ \\
Setup 1998 & -0.48 & -0.79 & -0.44 & -0.77 \\
Setup 1997 & $(0.58)$ & $(0.61)$ & $(0.58)$ & $(0.61)$ \\
& 0.16 & 0.13 & 0.14 & 0.1 \\
Market Share & $(0.47)$ & $(0.47)$ & $(0.49)$ & $(0.49)$ \\
Observations & 0.01 & 0.01 & 0.01 & 0.01 \\
R-squared & $(0.00)$ & $(0.00)$ & $(0.02)$ & $(0.02)$ \\
\hline
\end{tabular}

Dependent variable: Ratio of expenditure in $R \& D$ and in purchases of technology to sales of new goods during 1998-2000. Robust standard errors in parenthesis;* significant at $10 \%$; $* *$ significant at $5 \%$; *** significant at $1 \%$. Regressions only include firms that introduced new goods. City and industry effects included. 
Table 5: Ways in Which Firms Introduce New Varieties

\begin{tabular}{|c|c|c|c|c|c|c|}
\hline & \multicolumn{2}{|c|}{ Transferred } & \multicolumn{2}{|c|}{ Licensed } & \multicolumn{2}{|c|}{ In-house } \\
\hline & (1) & $(2)$ & $(3)$ & $(4)$ & $(5)$ & $(6)$ \\
\hline Majority (50-100\%) & $\begin{array}{c}0.20^{* * *} \\
(0.07)\end{array}$ & - & $\begin{array}{c}0.31^{* * *} \\
(0.08)\end{array}$ & - & $\begin{array}{c}-0.23^{* * *} \\
(0.08)\end{array}$ & - \\
\hline Majority $(50-100 \%) \times J V$ & - & $\begin{array}{c}0.27^{* * *} \\
(0.09)\end{array}$ & - & $\begin{array}{c}0.37^{* * *} \\
(0.09)\end{array}$ & - & $\begin{array}{c}-0.29^{* * *} \\
(0.09)\end{array}$ \\
\hline Majority $(50-100 \%) \times \mathrm{INV}$ & - & $\begin{array}{l}(0.15 \\
(0.15)\end{array}$ & - & $\begin{array}{c}0.46^{* * *} \\
(0.15)\end{array}$ & - & $\begin{array}{l}-0.14 \\
(0.14)\end{array}$ \\
\hline Minority (10-49\%) & $\begin{array}{c}0.02 \\
(0.07)\end{array}$ & $\begin{array}{c}0.02 \\
(0.07)\end{array}$ & $\begin{array}{l}-0.06 \\
(0.06)\end{array}$ & $\begin{array}{l}-0.06 \\
(0.06)\end{array}$ & $\begin{array}{c}0.00 \\
(0.08)\end{array}$ & $\begin{array}{c}0.00 \\
(0.08)\end{array}$ \\
\hline Non-private & $\begin{array}{c}-0.08^{*} \\
(0.05)\end{array}$ & $\begin{array}{c}-0.08^{*} \\
(0.05)\end{array}$ & $\begin{array}{l}-0.08 \\
(0.06)\end{array}$ & $\begin{array}{l}-0.09 \\
(0.06)\end{array}$ & $\begin{array}{l}-0.08 \\
(0.06)\end{array}$ & $\begin{array}{l}-0.07 \\
(0.06)\end{array}$ \\
\hline Observations & 362 & 354 & 380 & 372 & 399 & 391 \\
\hline
\end{tabular}

Probit regressions. Table reports the incremental probability with respect to the baseline category (private domestic firms). Dependent variables: 1-2 Transferred at least one new good from company in same corporate group during 1998-2000; 3-4 Purchased at least one license from a foreign source during 1998-2000; 5-6 Developed a new good in house, in China, during 1998-2000. Robust standard errors in parenthesis; $*$ significant at $10 \%$; $* *$ significant at $5 \%$; *** significant at $1 \%$. Regressions only include firms that introduced new goods. Other controls: Log workers, Log age, Setup 1997, Setup 1998, city and industry effects. 
Table 6: New Varieties and Productivity and Cost Advantages

\begin{tabular}{|c|c|c|c|c|}
\hline \multirow{3}{*}{ Panel A: Regression result } & \multicolumn{2}{|c|}{ Majority } & \multicolumn{2}{|c|}{ Majority $\times$ JV } \\
\hline & $\begin{array}{c}\text { Poisson } \\
(1)\end{array}$ & $\begin{array}{c}\text { IV Poisson } \\
(2)\end{array}$ & $\begin{array}{c}\text { Poisson } \\
(3)\end{array}$ & $\begin{array}{c}\text { IV Poisson } \\
(4)\end{array}$ \\
\hline & & & & \\
\hline Log Value added per worker & $0.21^{* *}$ & $0.34^{* *}$ & 0.13 & 0.24 \\
\hline Incidence ratio & $\begin{array}{c}1.23 \\
(0.09)\end{array}$ & $\begin{array}{c}1.4 \\
(0.16)\end{array}$ & $\begin{array}{c}1.14 \\
(0.12)\end{array}$ & $\begin{array}{c}1.28 \\
(0.17)\end{array}$ \\
\hline Cost of Development & $-0.16^{* * *}$ & $-0.13^{*}$ & $-0.15^{* * *}$ & -0.11 \\
\hline Incidence ratio & $\begin{array}{c}0.85 \\
(0.05)\end{array}$ & $\begin{array}{c}0.88 \\
(0.08)\end{array}$ & $\begin{array}{c}0.86 \\
(0.05)\end{array}$ & $\begin{array}{c}0.89 \\
(0.07)\end{array}$ \\
\hline Majority Foreign (50-100\%) & $\begin{array}{c}0.17 \\
(0.38)\end{array}$ & $\begin{array}{l}-0.07 \\
(0.50)\end{array}$ & - & - \\
\hline Majority Foreign $\times$ JV & - & - & $\begin{array}{c}0.29 \\
(0.41)\end{array}$ & $\begin{array}{c}0.14 \\
(0.54)\end{array}$ \\
\hline Majority Foreign $\times$ INV & - & - & $\begin{array}{l}-1.68 \\
(1.12)\end{array}$ & $\begin{array}{l}-2.05 \\
(2.03)\end{array}$ \\
\hline Minority $(10-49 \%)$ & $\begin{array}{l}-0.18 \\
(0.34)\end{array}$ & $\begin{array}{l}-0.52 \\
(0.71)\end{array}$ & $\begin{array}{l}-0.23 \\
(0.34)\end{array}$ & $\begin{array}{l}-0.57 \\
(0.69)\end{array}$ \\
\hline Non-private & $\begin{array}{l}-0.21 \\
(0.34)\end{array}$ & $\begin{array}{l}-0.51 \\
(0.41)\end{array}$ & $\begin{array}{l}-0.25 \\
(0.34)\end{array}$ & $\begin{array}{l}-0.64 \\
(0.42)\end{array}$ \\
\hline Market Share & $\begin{array}{c}0.01 \\
(0.00)\end{array}$ & $\begin{array}{c}-0.04^{* *} \\
(0.02)\end{array}$ & $\begin{array}{c}0.01 \\
(0.00)\end{array}$ & $\begin{array}{c}-0.04^{* *} \\
(0.02)\end{array}$ \\
\hline Log Workers & - & $\begin{array}{c}0.04 \\
(0.47)\end{array}$ & - & $\begin{array}{l}-0.11 \\
(0.53)\end{array}$ \\
\hline Log Age & $\begin{array}{c}0.07 \\
(0.19)\end{array}$ & $\begin{array}{c}0.16 \\
(0.49)\end{array}$ & $\begin{array}{c}0.07 \\
(0.19)\end{array}$ & $\begin{array}{c}0.28 \\
(0.54)\end{array}$ \\
\hline Setup 1998 & $\begin{array}{c}1.80^{* * *} \\
(0.64)\end{array}$ & $\begin{array}{c}2.39 \\
(2.14)\end{array}$ & $\begin{array}{c}1.99^{* * *} \\
(0.65)\end{array}$ & $\begin{array}{c}2.76 \\
(2.46)\end{array}$ \\
\hline Setup 1997 & $\begin{array}{l}-0.29 \\
(0.48)\end{array}$ & $\begin{array}{l}-0.26 \\
(0.70)\end{array}$ & $\begin{array}{l}-0.3 \\
(0.5)\end{array}$ & $\begin{array}{l}-0.17 \\
(0.81)\end{array}$ \\
\hline Observations & 238 & 236 & 236 & 234 \\
\hline Panel B: Contribution of & & & & \\
\hline Technology & 0.39 & 0.59 & 0.41 & 0.65 \\
\hline Labor productivity & 0.32 & 0.54 & 0.37 & 0.62 \\
\hline Cost of development & 0.06 & 0.05 & 0.04 & 0.03 \\
\hline Other factors & 0.20 & 0.36 & 0.09 & 0.18 \\
\hline Size & 0 & 0.02 & 0 & 0.04 \\
\hline Market share & 0.01 & 0.02 & 0.03 & -0.09 \\
\hline Initial year & -0.05 & -0.13 & -0.04 & -0.07 \\
\hline Industry and Location & 0.23 & 0.45 & 0.11 & 0.31 \\
\hline Unexplained & 0.42 & 0.05 & 0.50 & 0.16 \\
\hline
\end{tabular}

Robust standard errors in parenthesis; ${ }^{*}$ significant at $10 \%$; ${ }^{* *}$ significant at $5 \%$; ${ }^{* *}$ significant at $1 \%$. Regressions only include firms that introduced new goods. Regressions are conditional on the dependent variable being greater than zero. City and industry effects included. Panel B: Results show the percentage contribution of each explanatory variable to the predicted means of the index function between majority-owned foreign firms and private domestic firms. 
Table A1: Linear Regressions on Instruments

\begin{tabular}{lcc}
\hline & $\begin{array}{c}\text { Market Share } \\
\text { Taxrate }\end{array}$ & $\begin{array}{c}\text { Log Workers } \\
(1)\end{array}$ \\
\cline { 2 - 3 } Telephonedays & -0.55 & $-0.06^{* *}$ \\
& $(0.47)$ & $(0.02)$ \\
Disputes & $-0.53^{* *}$ & $-0.03^{* *}$ \\
& $(0.21)$ & $(0.01)$ \\
Losepower & -1.9 & $-0.58^{* * *}$ \\
& $(3.08)$ & $(0.17)$ \\
Majority (50-100\%) & 0.1 & -0.01 \\
& $(0.15)$ & $(0.01)$ \\
Minority (10-49\%) & -3.68 & $0.31^{* *}$ \\
& $(2.75)$ & $(0.15)$ \\
Non-private & $-8.30^{* *}$ & 0.05 \\
& $(3.45)$ & $(0.18)$ \\
Log age & -2.62 & $-0.41^{* * *}$ \\
& $(2.55)$ & $(0.14)$ \\
Setup 1998 & 0.22 & $0.94^{* * *}$ \\
Setup 1997 & $(1.68)$ & $(0.09)$ \\
& -0.38 & -0.08 \\
Observations & $(4.55)$ & $(0.25)$ \\
R-squared & -1.4 & 0.38 \\
F-test (p-value) & $(4.92)$ & $(0.27)$ \\
\hline & & \\
Deper & 619 & 634 \\
& 0.13 & 0.34 \\
& 0.08 & 0 \\
\hline
\end{tabular}

Dependent variable: Self-reported market share (column 1), and $\log$ Workers in 1998 (column 2). Instruments: tax rate, days to set up a phone line, days of power outage, disputes with business partners; all computed at the province-industry level. Robust standard errors in parenthesis; * significant at $10 \%$; ** significant at $5 \%$; ${ }^{* *}$ significant at $1 \%$. Regressions include city and industry effects. 